\title{
Long Black: \\ Export Controls as a Means of Addressing Coffee Price Instability
}

\author{
Alberto Gabriele \\ UNCTAD \\ David Vanzetti \\ The Australian National University
}

\begin{abstract}
The global coffee market is characterised by repeated long term price declines interspersed with positive spikes. Numerous solutions to the coffee price instability have been suggested. Ultimately, diversification away from coffee production is likely to be necessary, but some form of supply constraint has been proposed as a means of raising incomes for many poor producers in times of significant price falls. Given the demand for coffee is fairly unresponsive to changes in retail prices, limiting production of raw coffee is likely to raise revenues to producers globally and perhaps even to those limiting their production. Without necessarily advocating this approach, in this paper we estimate the likely changes in coffee prices and export revenues under various supply reduction scenarios to provide policy makers with an illustration of the order of magnitude of the benefits that might accrue to coffee exporting countries. Results indicate that, assuming export controls could be implemented as envisaged, a 10 per cent reduction of exports in the four major producing countries is likely to increase world prices by 17 per cent and increase these countries' export revenues by 6 per cent in the long run.
\end{abstract}

\footnotetext{
*Corresponding address: Alberto Gabriele, UNCTAD, Palais des Nations, CH-1211 Geneva, Switzerland, Tel: +41-22-9174887, E-mail: alberto.gabriele @ unctad.org. David Vanzetti, Crawford School of Economics and Goverment, The Australian National University, Canberra, ACT 0200, Australia, Tel: +61-2-6125-6555, Fax: +61-2-6125-8448, E-mail: david.vanzetti@anu.edu.au.
} 
Other coffee exporters would increase their exports and therefore would gain proportionally more. Further gains would result from the additional production of alternative crops.

- JEL classification: F13, Q17

- Keywords: Coffee, Trade, Modelling, Export quotas

\section{Introduction}

Coffee is one of the most important agricultural commodities traditionally exported by developing countries, with the global production estimated at about US $\$ 16$ billion in $2006^{1}$. Like other primary agricultural commodities, the world coffee market is characterized by high instability and, according to most observers, by secularly declining real prices.

Coffee is a tree crop, usually cultivated in mountainous areas where the land could not, under "normal" circumstances, be utilized as productively for alternative crops or for grazing purposes. Quality and yields are very different from one area to another, even with the same production techniques, but - again, under "normal" circumstances - they usually entail a certain amount of "rent". Thus, producers will continue to supply as prices fall, as they have few alternative uses for the land. There are also few alternative uses of farm labour, taking into account the labour requirements of the overall production cycle. These features have made producers slow to respond to the abnormally low and unstable international prices evident for several years. Declining prices have been aggravated by market liberalization in most producing countries and by a process of consolidation, both at the level of roasting companies and of international traders (Ponte 2003). These phenomena, along with changes both in production and roasting technologies and the entry of new low-cost producers, have profoundly modified the coffee economy in many countries.

After booming in 1986 and 1987 due to a perceived shortage caused by a drought in Brazil, world coffee prices slumped in 1989 with the dramatic collapse of the International Coffee Organization (ICO) quota system. The market stayed depressed for four years, until prices recovered due to a general reduction in overall supply and the 1994 frost in Brazil. Over-supply led to a new slump in 1996, and

$\overline{{ }^{1} \text { Global production of } 122.8}$ million (60 kg) bags valued at the ICO's composite price indicator of US96c/lb. 
in spite of a short-lived jump in 1997 due to the El Nino phenomenon, world coffee prices followed a on a downward trend. As a result, in 2001, world coffee prices at US\$0.46 per lb were less than half their level in 1995 in nominal terms, without adjusting for inflation. Production for the 2001 season was 108 million bags, with consumption relatively stable for several years at 110 million bags. Prices have risen since the low of 2001 and are currently around US $\$ 1.36$ per $\mathrm{lb}$ (March 2008). This is a significant improvement but still well below the peaks of the 1970s and late 1980s (see figure 1). Worldwide production has responded to the improved outlook and in 2006 was back up to previous levels of 126 million

Table 1. Global green coffee production, exports and prices, 1995 to 2007

\begin{tabular}{cccc}
\hline & $\begin{array}{c}\text { Production } \\
\text { Million bags }\end{array}$ & $\begin{array}{c}\text { Exports } \\
\text { Million bags }\end{array}$ & $\begin{array}{c}\text { Average price (fob) } \\
\text { US cts/lb }\end{array}$ \\
1995 & 87 & 68 & 138 \\
1996 & 103 & 78 & 102 \\
1997 & 99 & 80 & 134 \\
1998 & 108 & 80 & 109 \\
1999 & 116 & 86 & 86 \\
2000 & 115 & 89 & 64 \\
2001 & 108 & 90 & 46 \\
2002 & 123 & 88 & 48 \\
2003 & 105 & 86 & 52 \\
2004 & 117 & 91 & 62 \\
2005 & 111 & 87 & 89 \\
2006 & 126 & 92 & 96 \\
2007 & 117 & 95 & 107 \\
\hline
\end{tabular}

Source: ICO. $60 \mathrm{~kg}$ bags. Price is ICO composite indicator price.

Figure 1. Coffee Prices

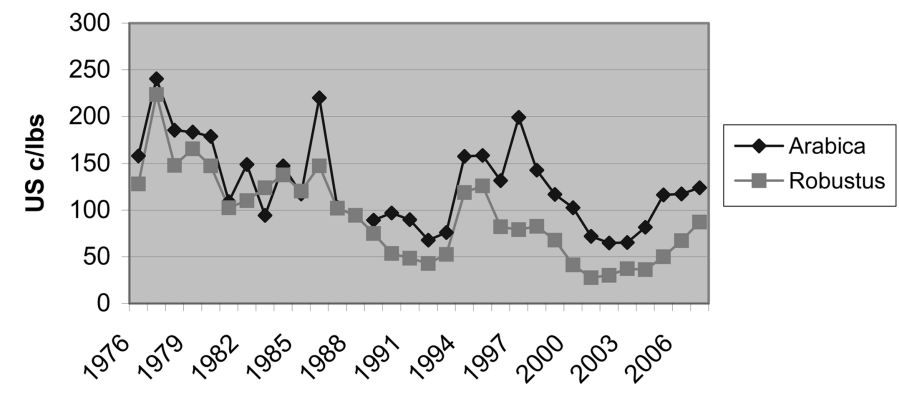

Source: ICO. Prices are for Colombian mild arabicas group and robustus group and are a weighted average of New York and German prices. There is a missing observation for arabica 1988 when the ICO quota system collapsed. 
Table 2. Coffee production and exports in four largest exporting countries 2006

\begin{tabular}{ccccc}
\hline & \multicolumn{2}{c}{ Production } & \multicolumn{2}{c}{ Exports } \\
& '000 bags & Share $\%$ & '000 bags & Share $\%$ \\
\hline Brazil & 42,512 & 35 & 28,402 & 30 \\
Colombia & 12,200 & 10 & 10,235 & 11 \\
Vietnam & 6,770 & 6 & 4,770 & 5 \\
Indonesia & 15,500 & 13 & 17,154 & 18 \\
& & & & \\
WORLD & 122,780 & 63 & 93,981 & 64 \\
\hline
\end{tabular}

Source: ICO.

bags. Most of the variation in production is accounted for by Brazil, where production fell by 20 million bags in 2003 before rising by 10 million bags the following year. (See tables 1 and 2, figure 1, FAO 2003, ICO 2008).

It is difficult to overestimate the impact of such dramatic market trends on a crop which is the main source of living for millions of poor and quasi-poor peasants, as well as the main (or one of the most important) contributors to foreign exchange earnings, to tax revenue and GDP in many developing countries. Some 70 countries in the world produce coffee, and 45 of them (nearly all belonging to ICO) account for over 97 per cent of world coffee output and exports. For nine of these countries the average share of coffee exports in total export earnings was over 20 per cent in the period 1996-2000, and for 24 - more than half the producer membership - it exceeded 5 per cent. These elements contribute to make coffee a "very political crop" (ITC 2002, p.3). Therefore, it is not surprisingly that, over the years, many producing country governments have participated in different attempts aimed at bringing about long term stability and larger benefits through several forms of cooperation in international coffee markets. Examples range from the Pancafe cartel in the 1970s, to the ICO quota system in the 1960s and again in the 1980s, to the scarcely effective retention plans promoted by the Association of Coffee producing Countries (ACPC) in the 1990s.

In spite of the recent lift in prices, the long-run slide in world coffee prices since the late 1970s led to a "coffee crisis", as coffee farming (especially by smallholders) has become economically unsustainable in many countries, with severe economic and social consequences (Ponte 2003) ${ }^{2}$. The urgency of coping

${ }^{2}$ The partial recovery of world coffee prices in the 2002/03 season was partly due to the exit from coffee production of many small-scale growers in traditionally coffee-producing countries. 
with such a crisis has prompted a renewed interest on the part of producing country governments on the advisability of negotiating a new and more effective international agreement. ${ }^{3}$ This paper is meant to provide some analytical and informational background that might be of use in such an endeavour. To this end, the next section reviews the history of international commodity agreements. The following section examines some of the potential difficulties of implementing an international agreement on coffee in a more deregulated environment, prior to a look at the issue of compatibility with WTO rules. The penultimate section presents the results of a (admittedly simplified and abstract) simulation exercise, aimed at estimating the likely impact of the enactment of various forms of supply management schemes on world prices, export revenues, and producer returns. A discussion of implications and limitations ends the paper.

\section{The Rise and Fall of ICAs: Is the Regulatory Approach Fashionable Again?}

Historically, structural difficulties of the kind referred to in the next section have plagued all attempts to regulate supply and prices in international commodity markets, especially so for traditional agricultural commodities. Attempts at international cooperation in trade in commodities can be traced back to the World Economic Conference held in Geneva in 1927 that recommended the establishment of international commodity agreements (ICAs) among exporting and importing countries. The case for ICAs received new momentum after World War II, leading the UN to create in 1947 an Interim Coordination Committee for International Commodity Agreements (ICCICA). The ICCICA was instrumental in negotiating four commodity stabilization agreements, including - for the first time - coffee (in 1962). The coffee ICA was probably the most successful in achieving, at least in the short term, its objectives of raising and stabilizing prices (Deaton and Laroque 1992 and Gilbert 1996, p.16).

However, after a few years it became apparent that the ICAs, with the possible exception of the tin agreement, were not functioning well, and the General Assembly transferred ICCICA's function to a newly-created agency, UNCTAD.

${ }^{3}$ Such a development had been foreseen already in the mid-1990s: "If commodity prices do prove to be in secular decline, one may expect to see some reinforcement of the tendency for producer organizations, such as that in coffee, to attempt to take unilateral action to manage supply in order to restore to historic levels. The recent history of ICAs, however, casts doubt on the likely success of these schemes" (Gilbert 1996, p.17). 
UNCTAD strongly supported the role of ICAs, but since the beginning it had to face the reservations, or the open opposition, of many developed countries. Market and intellectual trends worldwide were broadly favourable to commodity exporters in the 1970s, but were reversed in the subsequent decade. The 1980s saw a sharp decline in commodity prices, on one hand, and a change in the international political economy - from regulatory towards market-oriented approaches - on the other hand. Many developing countries sank into debt, and came under increased pressure to further expand their commodity exports, thereby worsening international market imbalances. Such disruptive trends led to the collapse of most ICAs, including the coffee agreement, and to a generalized loss of faith in the regulatory approach. ${ }^{4}$ In the case of coffee, in spite of the proven effectiveness of the export control mechanism per se in increasing and stabilizing the border prices received by exporting countries, the fourth quota-based agreement effectively lapsed in 1989 due to a combination of structural and transitory factors. ${ }^{5}$ Among the most important were: (i) the shift in consumer tastes towards Arabica, and importing countries' opposition to grade distortions between Arabica and Robusta beans and to price discrimination in favour of non-member importers; (ii) the conflicting views among coffee producing countries on the distribution of benefits from coffee trade, and within countries between growers and marketing boards; (iii) US Congress hostility to any form of active ICA; (iv) the Brazilian government's inconsistent coffee policy ${ }^{6}$; and (v) the widespread belief that the negative impact of the ending of supply controls would be short-lived ( Gilbert 1996, p.12).

By the end of the 1990s and the early 2000s, however, the weakening of world commodity markets and the declining enthusiasm for market based economic policies led the pendulum to switch again towards the search of some sort of regulation-based solutions. The idea that supply-management schemes and ICAs are advisable and rationally sound, at least in principle, has regained some intellectual and political respectability, and negotiations are continuing with a view

\footnotetext{
${ }^{4}$ Globalization, increasing international competition, and accelerated technical change are among other factors that tend to create conditions unfavorable to commodity cartels (see Gilbert 1996).

${ }^{5}$ A fifth international Coffee Agreements was negotiated in 1993-1994, but it did not contain any provision for direct market intervention.

${ }^{6}$ One of the first measures of the new Collor government in 1990 was the abolition of the Instituto Brasileiro do Café.
} 
to explore innovative and practical policy approaches to this issue. The consensus reached in September 2000 by 63 members of the International Coffee Council on a new six-year International Coffee Agreement aimed at to strengthening cooperation between consuming and exporting countries, albeit limited in scope, is an encouraging sign ${ }^{7}$. Yet, the bargaining position of (agricultural) commodity exporters in the international arena remains very weak, and action to supplement multilateral trade negotiations with concrete supply-side support has not yet materialized.

\section{Are Supply Management Schemes Feasible?}

To be able to implement export reduction policies, producers must overcome two types of obstacles. The first is the free rider problem, which implies that a share of the benefits of supply controls are captured by those not bearing the cost. The aim of this paper is to show, under different scenarios, the likely impact on prices and export revenues of export reductions by major coffee producers. The second set of obstacles relates to the ability of policymakers to control production in their own countries, which is constrained by a number of structural features of the coffee sector worldwide.

(i) On the production side, the coffee industry is very heterogeneous. Few countries are significant producers and exporters of both Robusta and Arabica coffees, yet this happens to be the case for the Brazil, the largest coffee producer worldwide. Quite apart from the two varieties issue, in many producer countries, and especially in those large and semi-industrialized ones who are the world leading exporters, coffee is produced on different types of lands, with different techniques and a wide range of yields and quality differentials. To the extent possible in a modelling exercise, such inter-country structural differences are taken into account in our exercise, as they are reflected in different country-specific supply elasticities.

(ii) From an institutional, organizational, and political economy viewpoint, producer countries are also very diverse. In the case of coffee, as in that of most other agricultural activities in developing countries, a common factor is the decline of institutions and organizations which used to promote and regulate coffee production at the national level, such as producers' associations, marketing boards,

${ }^{7}$ The agreement entered into force provisionally on October 1, 2001. 
state-run or state-regulated trading organizations, and the like. ${ }^{8}$

(iii) The "political economy of coffee" is not the same in every country either. In some countries, coffee production and exports have an immediate impact on the livelihood of a vast part of the rural population, and are a basic feature of the country's macroeconomic prospects and stability. In other countries, coffee plays a secondary role. In some countries, coffee producers are a well-organized socially homogeneous group constituting a powerful lobby. In other countries, they are internally divided and poorly organized. Besides that, the degree of compatibility between the specific interests of coffee producers and the priorities of the overall government's development strategy varies from one country to the other. Finally, in some countries coffee producers might represent particularly sensitive social groups (for instance, because they are largely constituted by ethnic minorities) and/ or coffee growing areas could be considered of particular strategic relevance by the national government (due, for instance, to geo-political reasons, or to endemic civil disturbances in remote, mountainous regions). In sum, governments in different producing countries could face difficulties in trying to implement coffee policies.

\section{Is a Coffee Supply Management Scheme WTO Compatible?}

The practical implementation of a supply management scheme on the part of major coffee exporters would require the solution of many policy-related technical, organizational, managerial, logistic, and legal problems (see section 2). Moreover, of course, it would constitute a major political decision on the part of these countries' governments. These issues are clearly beyond the scope of the present paper, which simply aims at exploring the possible quantitative impact of such a scheme under very stylized assumptions. Therefore, in this section, we examine the compatibility of any coffee supply management scheme with WTO rules. The case is not clear, but there appears to be sufficient elements in the WTO agreements to authorize developing countries to implement such a scheme. After due consideration an UNCTAD (2003b) Note concludes: "The case for reinforcing

\footnotetext{
${ }^{8}$ In this respect, a gradual reversal of the trend towards deregulation is probably needed, along with a gradual effort to re-build basic rural organizational, infrastructural, and regulatory networks and institutions, along with specific actions aimed at strengthening existing regulatory and trade-managing capacities in the coffee chain. Such institution-building efforts would constitute welcome incremental steps to improve each producer country's ability to retain a degree of control of its own domestic coffee economy, and to carry out whatever strategy in the domain of coffee production and trade it might deem worth pursuing, including those referred to in this paper.
} 
international management of supply of commodities by producing countries is now gaining ground" (sub-section on producer-producer cooperation-supply management". In a specific paragraph on "legal issues", the Note observed that the "general exceptions" to impose restrictions on production, imports and exports contemplated in GATT 1994, Article XX apply to commodity agreements of which both exporting and importing countries are members, "if they are imposed in pursuance of the obligations which such agreements impose". Moreover, "Articles XI and XXXVI also "contain wording that could allow such restrictions". Yet, the Note also cautioned that these articles apply to agreements among governments. "Agreements among the private sector may be challenged under the national competition laws which, inter alia, prohibit arrangements for "price fixing". However, in the case of commodities produced by developing countries, it should be considered that "developed countries themselves interfere with the laws of the market place by agricultural subsidies which deprive the developing world commodity exports of the right to compete for markets and are essentially "commodity agreements" to stabilize and guarantee incomes of developed world farmers".

Such views were generally upheld in the debate, and the final Report of the Meeting stated:

"In the short term...measures to reduce the supplies put on the market may be necessary. Where appropriate and feasible, these may include producer-consumer schemes, joint measures by producers only, and national-level measures.... Countries that are not party to these schemes should agree to apply a favourable interpretation of GATT Articles XI, XX and XXXVI, as well as other relevant articles of GATT and WTO Agreements, and to forgo using competition policy measures against such schemes. Developed countries should eliminate subsidies, where feasible, to contribute to reducing oversupply" (UNCTAD 2003a, para 17).

Apart from the rhetoric, in reality WTO members are concerned about measures that stimulate rather than constrain production. In addition, there are numerous examples of supply managed industries, for example in dairy, sugar and poultry sectors in many countries in Europe, plus the United States, Canada and Japan.

The result of this complex set of factors is that even to get key players to agree on a supply management scheme constitutes a major feat, let alone to ensure its

\footnotetext{
${ }^{9}$ The note observed that indeed there appears to be an increasing trend among competition authorities in developed countries to challenge cartels, as was showed by the case of the anti-trust suit in the US against De Beers and GE, accused of conspiring to fix the price of diamonds.
} 
proper and prompt implementation and, more crucially, its sustainability, at least in the medium term. Taking into account the troubled history of ICAs in general, and of that on coffee in particular, the scenarios presented in the following sections are to be seen as indicative, aimed at showing the scope and distributional effects of export control assuming they could be implemented.

\section{Modelling Supply Controls in the Coffee Market}

UNCTAD's Agricultural Trade Policy Simulation Model (ATPSM) is a static, partial equilibrium multi-commodity model. ${ }^{10}$ As such, it is not designed to analyse the transition from a crisis to a sustainable equilibrium. ${ }^{11}$ However, the model can be used to simulate the potential impact of supply management schemes. The attractions of the model are the country coverage (161 countries), the links to other sectors (such as tea), and its links to downstream processing (in the present case, roasted coffee).

As the model is not dynamic and it does not include a treatment of stocks, it cannot simulate the transitional effects of a change in production. Such effects are of course of interest as well, but for the purposes of the present analysis knowing where the market is going is more important than how it gets there.

In fact, from a theoretical point of view, the static nature the model means that its results are to be interpreted as those which would prevail in the long run once all the forces interacting directly and indirectly in the world coffee market lead to a stable equilibrium. Due to the peculiar nature of the coffee industry, and in particular to coffee's long and complex production cycles, such theoretical long run equilibrium might be reached after 5-10 years. However, in practice, under a scenario where a certain number of large coffee producers effectively decrease their coffee exports according to an agreed-upon supply management scheme, the impact on world price is actually likely to be direct and quasi-immediate (i.e., a few months), particularly if agents believe the agreement will hold. As far as producers manage to rein in world coffee supply (a necessary implicit assumption if this papers' results are interpreted in a long run perspective) the initial impact on price is likely to be long-lasting, leading to a new equilibrium which - in absence

\footnotetext{
${ }^{10}$ See Appendix 1 for a description of the ATPSM modeling framework.

${ }^{11}$ See Vanzetti and Sharma (2002) and Vanzetti and Peters (2003) for model description and typical applications of ATPSM.
} 
of further shocks - could prevail indefinitely, and therefore is to be seen as a long run one.

The ATPSM data set includes 36 agricultural commodities. Among them are substitutes in demand such as tea and (possibly) cocoa, and substitutes in production, such as maize and tea. Substitutes in production are of interest because diversification away from coffee is seen as a long-term solution for the industry. The impacts of diversification are not adequately captured without these alternatives. Their absence suggests resources (labour, capital, land) moved out of coffee are wasted whereas in reality there is some scope for producing alternative crops such as tea or maize. This generates additional revenue but may also have the affect of lowering prices for existing producers of these crops.

The model also includes roasted coffee. The link between the growing sector and the processing sector is of interest because changes in the relationship between green and processed coffee may be contributing to the decline in bean prices. There is also evidence to suggest that roasters can now produce good quality coffee from the qualitatively inferior and cheaper Robusta variety, a technical change that might cause a fall in demand for the more expensive Arabica in the long run ${ }^{12}$. Changes in world demand for processed coffee (where many traditional European and North American markets are reaching the point of saturation, while coffee consumption is projected to grow fast in Japan and other Asian countries) have repercussions on the demand for green coffee, and such a backward linkage can also be explored by means of model simulations.

Finally, ATPSM includes trade policy data. Trade liberalisation has been suggested as a solution to the coffee problem. Yet, our results show that this is not the case, as there is little protection on coffee in the major importing market (see below, subsection 4.1). The ATPSM modelling framework includes production controls as a policy instrument.

ATPSM models the interdependences between green and roasted coffee. Virtually all green coffee is roasted, and all processed coffee is the major ingredient in roasted coffee, although processors have some scope to mix their blends. Because of this rather inflexible relationship in processing, the supply of green coffee limits the production of processed coffee. Thus a requirement of the model is the change in supply of processed coffee (equation 2) is equal to the consumption of green coffee (equation 1). There is no change in stocks in the

\footnotetext{
${ }^{12}$ The present, short-term trend in world coffee market point towards the opposite direction, as a drop in Robusta production has led to an increase in its price relative to that of Arabica(see above, section 1).
} 
model. This means that one equation effectively becomes redundant.

The model solves by finding a market clearing world price that equates changes in global imports and exports. This also implies that the change in global production equals the change in consumption. To simulate a production quota, the supply curve is shifted to the left by the required amount and the own price elasticity is set at zero.

The exogenous fall in output leads to an increase in world prices that is determined by the supply and demand elasticities. Producers in non-limiting countries (free riders) are likely to respond by increasing output, exports and revenues. They are unambiguously better off. Producers in the production limiting countries may be better or worse off depending on the number of producers involved and the parameters in the model. The impacts on 161 countries can readily be calculated.

\section{A graphical exposition}

A diagrammatic representation of a selling arrangement, better known as a cartel, can be seen in figure 2. Prior to a supply management arrangement the potential cartel members and non-members export Xc and Xf respectively at price Pw. The Rest of World imports Mc which must equal Xc and Xf. If the cartel members withhold supply from the market, as indicated by the vertical supply curve Sc', the world price will shift upwards to $\mathrm{Pw}^{\prime}$ to equate global imports and exports. Global imports Mc will decrease, as determined by the intersection of the new world price with the supply ( $\mathrm{Sr}$ ) and demand (Dr) curves, but some of the benefits of the higher price will be captured by the fringe exporters, who respond by increasing exports. Whether the change in export revenues in the cartel is positive or negative depends on whether the world price increase outweighs the fall in exports.

Figure 2. Modelling supply with binding production quota

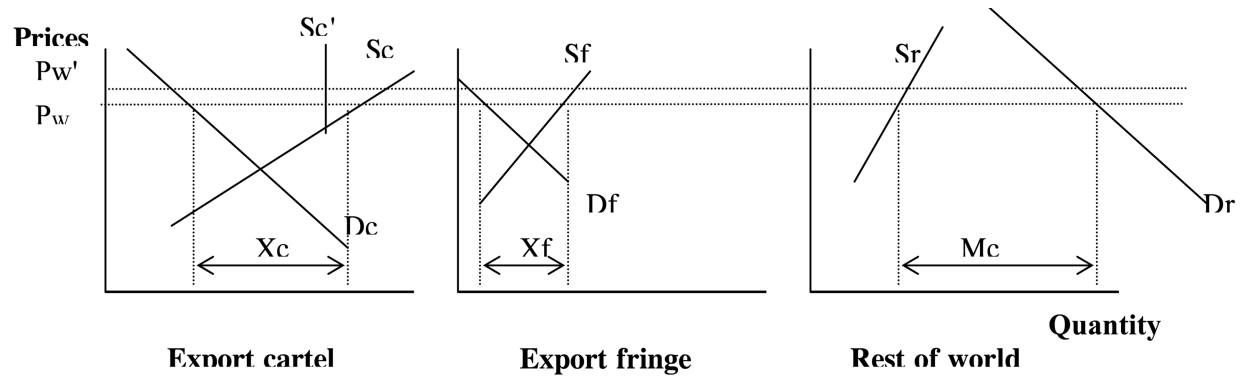




\section{Data}

The model covers 160 individual countries plus one region, the European Union, which includes 15 countries. Volume data are from 1999 to 2001 and are compiled from FAO supply utilisation accounts ${ }^{13}$. The price data are derived from ICO and an average of the three years 2003-2005. Elasticity data for coffee were obtained from FAO's dynamic, single commodity coffee. This has short-run own price elasticities and no cross elasticities. The short run elasticities for each country were converted to the long run by dividing by one minus the adjustment parameter. The average long-run supply elasticity is around 0.25 suggesting that a fall in output is likely to generate increases in revenues. The elasticities of demand and supply are given in table A1 for selected countries. The elasticities may seem rather low, but during the more than doubling of prices since 2001, production in Colombia, Indonesia and Vietnam has hardly moved. Brazilian production has increased by 35 per cent, much less than the price increase.

\section{Scenarios, Assumptions, and Results}

In the first simulation exercise presented in this section, free trade is modelled to demonstrate that this is not a solution to the declining coffee prices. The remaining scenarios focus on supply management. One, two or four major coffee exporting countries are assumed to restrict their coffee exports. Policy tools such as production and export quotas, export taxes ${ }^{14}$, and planned changes ${ }^{15}$ in stocks

\footnotetext{
${ }^{13}$ See FAOSTAT at http://www.fao.org.

${ }^{14}$ Moderate rates of export taxation are a feasible policy tool, especially for countries with significant market shares. They can also contribute to partially shield growers from price volatility, and to indirectly motivate diversification towards non-traditional crops (Gilbert 1999). At present there is no WTO no prohibition against export taxes.

${ }^{15}$ As previously explained, for the sake of simplicity, the model assumes that supply schedules in countries reducing coffee exports are zero, so that (exogenous) reductions in exports are equal (in percentage terms) to reductions in production. However, if exporting countries were able to increase the share of domestic production kept in stocks - by itself, not a very appealing policy choice - they could anyway achieve the desired reduction in coffee exports, and the results presented in this section would still be valid.

${ }^{16}$ If only one country (Brazil) is assumed to cut coffee exports, it might choose either of these instruments alone or a combination of them. In the more interesting scenarios where two or more coffee exporters agree on a supply management scheme, countries might also agree upon a uniform set of policy measures aimed at achieving the desired outcome, or leave such a choice entirely to each government, as far as the main quantitative goal in terms of export reduction is achieved.
} 
Table 4. Scenarios

\begin{tabular}{cll}
\hline Number & \multicolumn{1}{c}{ Label } & \multicolumn{1}{c}{ Description } \\
\hline 1 & $\begin{array}{l}\text { Trade } \\
\text { liberalisation }\end{array}$ & Elimination of all tariffs on all agricultural commodities \\
2 & $\begin{array}{l}\text { Single } \\
\text { country constraint }\end{array}$ & Exports constrained in Brazil \\
3 & Two country cartel & Exports constrained in Brazil and Colombia \\
4 & Four country cartel & Exports constrained in Brazil, Colombia, Vietnam and Indonesia \\
\hline
\end{tabular}

might be used to achieve the desired export targets, alone or in combination. ${ }^{16}$ The aim here is to assess the number of countries and the size of the production cut necessary to sustain a successful cartel. The greater the number of countries, the lower is the necessary production cut but the greater the difficulty in keeping the cartel together.

\section{A. Trade liberalization}

Results of the trade liberalisation scenario are shown in table 5. Because there are relatively few barriers in the major importing countries to coffee trade, and, in the model at least, there is insufficient scope for coffee producers to switch to other activities (maize, beef) whose prices rise following trade liberalisation. The major importers the United States, the European Union and Japan have tariff duties of zero, 6 and 6 per cent respectively on raw coffee and 8 per cent on processed coffee in the European Union. As a result the change in world price for coffee following complete liberalisation of agricultural products is only 0.5 per cent for Arabica and 1.3 per cent for Robustas. This generates an increase of $\$ 105$ million in raw coffee export revenues. Existing coffee producers would also gain from higher prices of other commodities. However, producers in some developing countries have very high tariffs and would be worse off if these tariffs were removed. For example, the Philippines and Malaysia lose when the elimination of

Table 5. Impact of complete trade liberalisation on coffee producers

\begin{tabular}{cccc}
\hline & $\begin{array}{c}\text { World price } \\
\%\end{array}$ & $\begin{array}{c}\text { Export revenue } \\
\$ \mathrm{~m}\end{array}$ & $\begin{array}{c}\text { Producer surplus } \\
\$ \mathrm{~m}\end{array}$ \\
& & & \\
Arabica & 0.5 & 68.9 & 30.1 \\
Robustas & 1.3 & 35.5 & -25.1 \\
\hline
\end{tabular}

Source: ATPSM simulations 
significant border protection reduces domestic prices by 27 and 40 per cent respectively. The pattern of trade and protection results in Arabica producers being better off globally whereas Robusta producers would be worse off.

\section{B. Brazil reduces coffee exports}

Table 6 shows the main results of the second scenario in which only Brazil, the largest coffee producer and exporter with over 20 per cent of the world market, cuts its exports, while all other producer countries do not. With a 10 per cent cut in Brazil's coffee exports, the increase in the world coffee price is 7 per cent. Brazil's export revenues fall by 2 per cent but those of the fringe (non-member) exporters rise by 11 per cent. With a larger cut (20 per cent), Brazil's revenue loss increases to 5 per cent. Therefore, in spite of its sizeable market power, there is no unilateral strategy of supply management that could benefit Brazil.

\section{Brazil and Colombia reduce coffee exports}

Colombia is the second largest world coffee exporter. ${ }^{17}$ Together, Brazil and Colombia supply over a third of world coffee exports, enough to raise world prices by more the cut in production. If the two South American producers were to enforce a bilateral agreement to each cut coffee exports by ten per cent, the resulting percentage increase in world coffee prices would be 10.5 per cent. This would be just sufficient to allow Colombia and Brazil to marginally increase their export revenue - without requiring any compensation from other coffee producers.

Table 6. Impact of Brazilian export retention

\begin{tabular}{lcc}
\hline & $\%$ & $\%$ \\
Assumed change in Brazilian exports & -10 & -20 \\
& & \\
Change in world price & 7.3 & 14.7 \\
Change in Brazil's export revenues & -1.6 & -5.1 \\
Change in fringe export revenues & 11.1 & 22.8 \\
Change in LDC export revenues & 11.7 & 24.1 \\
\hline
\end{tabular}

Source: ATPSM simulations

\footnotetext{
${ }^{17}$ In the 1990s, Vietnam established itself as the world's third largest coffee exporter. Actually, Vietnam's coffee exports were even larger than Colombia's in the late 1990s - the period on which the base ATPSM scenario presented in this paper is based - but fell thereafter. Thus, in the early 2000s, Colombia has re-gained its structural rank as second coffee exporter, which it appears poised to maintain for the foreseeable future.
} 
Table 7. Impact of two-country export retention scheme

\begin{tabular}{lcc}
\hline & $\%$ & $\%$ \\
\hline Assumed change in member exports & -10 & -20 \\
& & \\
Change in world price & 10.5 & 20.9 \\
Change in members' export revenues & 3.4 & 3.8 \\
Change in fringe export revenues & 16.4 & 34.4 \\
Change in LDC export revenues & 16.9 & 35.1 \\
\hline
\end{tabular}

Source: ATPSM simulations. The two countries are Brazil and Colombia.

The main implication from this result is that at least two countries of the size of Brazil and Colombia need to participate in any supply management scheme to make it self-sustaining. With lesser cooperation, the percentage change in world prices would not exceed the percentage reduction in exports, and hence export revenues would fall.

\section{Brazil, Colombia, Indonesia, and Vietnam reduce coffee exports}

This scenario features the four main coffee producers jointly reducing their exports. Four is a sufficiently small number to be able to enforce an agreement, but large enough to have an impact. Together, Brazil, Colombia, Indonesia, and Vietnam control half of the world market (53 per cent of export revenues) high enough to be able to achieve a strong impact on world prices and their own export revenues. ${ }^{18}$ With a ten per cent change in exports in these four countries world prices rise by 17 per cent and member country export revenues by 7 per cent. The gains would be more pronounced with a 20 per cent cut, but would be lower if the exports reduction were pushed to 30 per cent ${ }^{19}$. The gains to (free-riding) nonmembers are, proportionally, even more substantial. Price rises are passed on to processors and consumers.

Export revenues, however, are not a fully satisfactory measure of producer returns. On one hand, an increase in the export price also boosts the value of domestic sales, assuming world price increases are transmitted to the domestic market. One the other hand, export revenues do not reflect the cost of production.

\footnotetext{
${ }^{18} \mathrm{As}$ in other scenarios, the implicit assumption is that the remaining coffee exporters free ride, obtaining proportionally higher benefits from the impact on world prices from the supply management scheme than the countries engaged in the export reduction exercise, and do not share such benefits with them.

${ }^{19}$ The results of the 30 per cent exports reduction scenario are not shown
} 
Table 8. Impact of four-country export retention scheme

\begin{tabular}{lcc}
\hline & $\%$ & $\%$ \\
Assumed change in member exports & -10 & -20 \\
& & 33.8 \\
Change in world price & 16.9 & 10.3 \\
Change in members' export revenues & 7.0 & 63.6 \\
Change in fringe export revenues & 29.5 & 59.3 \\
Change in LDC export revenues & 27.9 & \\
\hline
\end{tabular}

Source: ATPSM simulations. The four countries are Brazil and Colombia, Indonesia and Vietnam.

Table 9. Impact of four-country ten per cent export retention scheme on producer surplus

\begin{tabular}{cc} 
& Producer surplus \\
& $\$ \mathrm{~m}$ \\
Brazil & 489 \\
Colombia & 170 \\
Indonesia & 126 \\
Vietnam & 162 \\
Fringe & 1264 \\
LDCs & 229 \\
World & 22117 \\
\hline
\end{tabular}

Source: ATPSM simulations. The four countries are Brazil and Colombia, Indonesia and Vietnam. Fringe includes all non-cartel members.

As exports and production are increased, the inputs into production are increased more than proportionately. This reflects the upward sloping supply curve, which implies that at the margin additional production is increasingly expensive to produce. The concept of producer surplus was developed to take into account these indirect effects. ${ }^{20}$ The global change in producer surplus in the coffee market, including the processing sector, is $\$ 22,117$ million, which compares with a change in export revenue of $\$ 1,307$ million.

\section{The Impact on LDC Coffee Exporters}

As shown in Table 10, 19 LDCs are coffee exporting countries, and jointly contribute around 10 per cent of total coffee production and exports. Two of them, Uganda and Ethiopia, are among the world's largest exporters, with over US\$200

\footnotetext{
${ }^{20}$ Producer surplus can be thought of as revenues minus costs.
} 
million export revenues each in 1998-2000 and a combined share of world coffee exports of almost 5 per cent. The other LDC exporters are small players in the world coffee market.

The relative importance of coffee in several LDC economies is rather high. Moreover, as coffee is a labour intensive crop, the social role of the coffee sector is even more relevant than its sheer macroeconomic weight, because in many countries it constitutes the only sizeable source of income for many of the rural poor, especially for landless peasant and subsistence farmer households. As a result, the economic effects of declining coffee prices are particularly acute among LDCs.

Under the scenario where the four largest exporters reduce their coffee exports by ten per cent, LDC coffee exporting countries would benefit both from the world price increase and the upward movement along their supply curve, reaching an equilibrium characterized by higher coffee production, exports in volume, and export revenues (see table 10). All countries would be net beneficiaries.

Table 10. Impact of four-country export retention scheme on LDCs

\begin{tabular}{lcccc}
\hline & $\begin{array}{c}\text { Initial export } \\
\text { revenue } \\
\$ \mathrm{~m}\end{array}$ & $\begin{array}{c}\text { Export } \\
\text { revenue share }\end{array}$ & $\begin{array}{c}\text { Change in } \\
\text { export revenue }\end{array}$ & $\begin{array}{c}\text { Change in } \\
\text { export revenue }\end{array}$ \\
& 39.9 & 0.41 & 8.1 & $\%$ \\
\hline Burundi & 10.7 & 0.11 & 2.5 & 21.1 \\
Central African Republic & $*$ & $*$ & $*$ & 23.8 \\
Cambodia & 0.0 & 0.00 & 0 & $*$ \\
Cape Verde & 54.2 & 0.55 & 8.0 & 0.0 \\
Congo D.R. & 220.6 & 2.25 & 5.2 & 14.8 \\
Ethiopia & 21.9 & 0.22 & 3.8 & 23.6 \\
Guinea & 8.9 & 0.09 & 4.9 & 17.4 \\
Haiti & 28.8 & 0.29 & 6.0 & 54.7 \\
Laos & $*$ & $*$ & 11 & 20.9 \\
Nepal & 24.4 & 0.25 & 6.5 & $*$ \\
Rwanda & $*$ & $*$ & 21 & $* .3$ \\
Sao Tome & 3.9 & 0.04 & 1.6 & 41.5 \\
Sierra Leone & 83.5 & 0.85 & 17.9 & 21.5 \\
Tanzania & 25.0 & 0.25 & 4.0 & 15.8 \\
Togo & 264.5 & 2.70 & 52.1 & 19.7 \\
Uganda & 4.9 & 0.05 & 1.8 & 37.8 \\
Yemen & 9.0 & 0.09 & 1.4 & 15.8 \\
Zambia & 821.0 & 8.37 & 17.1 & 20.8 \\
Total LDCs & & & & \\
\hline Source: ATPSM & & & & \\
\hline
\end{tabular}

Source: ATPSM simulations. The four countries reduce exports by 10 per cent.

- denotes negligible. 


\section{Implications, Limitations and Conclusions}

The results suggest that withholding production from the market could increase export revenues if countries responsible for at least 30 per cent of the global exports participate. This would require Brazil and at least one other country, Colombia or Vietnam. Realistically, four countries responsible for 50 per cent of the market would be required to generate substantial gains. With a ten per cent reduction in exports, revenues are estimated to increase by 6 per cent in member countries and around 30 per cent in non-member countries, including LDC exporters. Thus the bulk of the gains accrue to non-members, and this represents a stumbling block to the formation of such an agreement.

Cartel arrangements are notoriously unstable because of the incentives of members to renege on the agreement. For example, under the four by ten per cent arrangement, the average export revenue of members increases by 7 per cent, whereas fringe exporters gain by 30 per cent (table 8 ). There is always the temptation for individual members to take advantage of the revenue differential by increasing exports beyond the agreed limit. Such a defection, of course, would weaken the agreement to the detriment of all except the ex-member. To enforce such agreements, therefore, it is useful to have a penalty clause that ensures that the agreement collapses if one member leaves. This ensures that all would lose. The difficulty here is maintaining credibility, as there is an incentive for the remaining members to renegotiate.

Taking into account that the political and institutional challenge of managing and sustaining the supply management scheme tends to become progressively more formidable with ever larger export reduction targets, these results suggest that a moderate goal (in the range, tentatively, of a 10 per cent to 20 per cent export cut) might be preferable to a more ambitious one. A four-member agreement is also likely to be more stable and enforceable than one with many more members.

Limitations of the analysis include its static nature. We say nothing about the transition from the current crisis situation to a new equilibrium. This is more important with tree crops where there is a large investment component in the decision to produce or diversify to alternatives. The cross elasticities, reflecting the scope for diversification, are also scarce. The model is essentially linear and the effects of large changes are untested. Marketing margins are assumed to be constant, whereas there might be some value in treating processors as monopolistic and able to absorb some of the price increases following from reduced output. In 
spite of these limitations, the key variables are the elasticities, and given these are reasonable the main results are likely to be fairly robust.

In sum, this paper analyses some intrinsic properties of the world coffee market under somewhat simplified assumptions. In this stylized scenario, a reduction in exports on the part of few major producers would lead to a significant raise in world coffee prices. However, in drawing policy lessons these results should be interpreted with care, as the model has abstracted from changes in history and institutions that affect the operation of markets. The globalizing international economy of the early 2000s is quite different from that of the 1960s and 1970s. More open and competitive international trading systems make the maintenance of supply retention more difficult. Moreover, the demise of past ICAs has shown clearly that - at least, as far as agricultural commodities are concerned international producer agreements are not tenable in the long run if, as a result of their own success, they cause increasing tensions between the interests of the various stakeholders in the different participating countries. Besides that, any attempt to increase revenues from traditional agricultural exports should be seen as a temporary arrangement to smooth the progressive transition towards other agricultural and non-agricultural sectors and sub-sectors. Any internationallyagreed reduction in coffee production can only be useful as a short term measures if it is accompanied by a structural shift of resources towards other activities, in the framework of a market-compatible diversification strategy. There is a range of food and cash crops that coffee producers may diversify into (see Coelli and Fleming (2004) for a detailed discussion of opportunities and limitation for smallholders in Papua New Guinea). Developed countries could assist this process by removing existing restrictions on market access to the alternatives into which coffee producers may diversify. For their part, developing country governments could assist the process by developing appropriate institutions to provide the necessary research, development and marketing services, such as forecasting and risk management.

\section{Acknowledgements}

The ATPSM modelling framework was initially developed by UNCTAD and further refined by FAO and UNCTAD. The contribution of funding from DFID is gratefully acknowledged.

The opinions expressed in this paper are those of the authors and do not 
necessarily reflect the views of UNCTAD or its members. The designations and terminology employed are also those of the authors.

The authors thank Alyssa Nevin of UNCTAD for assistance with collection and analysis of data. George Rapsomanikis of FAO provided data and helpful comments on a draft of the paper.

Received 7 August 2007, Accepted 14 January 2008

\section{References}

AMAD database http://www.amad.org.

Branchi M., Gabriele A., Spiezia V., 1999, Traditional agricultural exports, external dependency, and domestic trade policies - African coffee exports in a comparative perspective", UNCTAD Discussion Paper No.140, February 1999.

Coelli, T. and Fleming, E (2004) 'Diversification economies and specialisation efficiencies in a mixed food and coffee smallholder farming system in Papua New Guinea' Agricultural Economics 31 (2-3), 229-239.

Deaton A. and Laroque G., 1992, 'On the behaviour of commodity prices', Review of Economic Studies, Vol.59, pp.1-23.

Gilbert C.G. 1996, 'International commodity agreements: An Obituary Notice', World development, Vol.24, No.1, pp.1-19.

Gilbert C.G. 1999, 'Coffee and cocoa liberalization - Issues for the future', in $w w w$ econo.economia.unitn.it/cgilbert/USAID_

FAO 2003, Coffee Commodity Notes, 17/11/2003.

International Trade Center, 2002, Coffee- An exporter's guide, Geneva.

Ponte S., 2003, Standards and Sustainability in the Coffee Sector: A Global Value Chain Approach, Paper presented to the Multi-Stakeholder Meeting: Sustainability in the Coffee Sector: Exploring Opportunities for International Cooperation, UNCTADIISD, 8-9 December 2003, Palais des Nations, Geneva.

UNCTAD TRAINS database http://www.unctad.org/trains/index.htm.

Vanzetti, D. and R. Sharma (2002). "Impact of Agricultural Trade Liberalisation on Developing Countries: Results of the ATPSM Partial Equilibrium Model”, invited paper at the International Agricultural Trade Research Consortium summer symposium on "The Developing Countries, Agricultural Trade and the WTO" Whistler Valley, British Columbia, Canada, 16-17 June.

Vanzetti, D. and Peters, R. (2003) 'Making sense of agricultural trade policy reform', 25 International Conference of IAAE, Durban, South Africa, 16-22 August. 


\section{Appendix}

\section{Appendix 1. The ATPSM modelling framework}

The system is built upon four equations for each country, specifying domestic consumption, production, exports and imports:

$$
\begin{aligned}
& \text { 1) } \hat{D}_{i, r}=\eta_{i, i, r}\left[\hat{P}_{w i}\left(1+\frac{\Delta t_{c i, r}}{1+t_{c i, r}}\right)\right]+\sum_{\substack{j=1 \\
i \neq j}}^{J} \eta_{i, j, r}\left[\hat{P}_{w j}\left(1+\frac{\Delta t_{c j, r}}{1+t_{c j, r}}\right)\right] \text {; } \\
& \text { 2) } \hat{S}_{i, r}=\varepsilon_{i, i, r}\left[\hat{P}_{w i}\left(1+\frac{\Delta t_{p i, r}}{1+t_{p i, r}}\right)\right]+\sum_{\substack{j=1 \\
i \neq j}}^{J} \varepsilon_{i, j, r}\left[\hat{P}_{w j}\left(1+\frac{\Delta t_{p j, r}}{1+t_{p j, r}}\right)\right] \\
& \text { 3) } \Delta X_{i, r}=X_{i, r} \hat{S}_{i, r} \\
& \text { 4) } \Delta M_{i, r}=D_{i, r} \hat{D}_{i, r}-S_{i, r} \hat{S}_{i, r}+\Delta X_{i, r}
\end{aligned}
$$

where $D, S, X$, and $M$ denote demand, supply, exports and imports respectively,

$\wedge$ denotes relative changes and $\Delta$ absolute changes, $P_{w}$ denotes world price, $t_{c}$ denotes the domestic consumption tariff and $t_{s}$ denotes the domestic production tariff, $\varepsilon_{i, i, r}$ denotes supply elasticity and $\eta_{i, i, r}$ denotes demand elasticity, $\mathrm{i}$ and $\mathrm{j}$ are commodities indexes and $\mathrm{r}$ is a country index. The changes in demand and supply are functions of own and cross prices and their respective elasticities. Equation 3 specifies the change in exports to be a function of the change in production. The ratio between production and exports is maintained. This also implies the percentage change in production equals the percentage change in exports. ${ }^{21}$ The fourth equation requires that imports are determined to clear the local market, that is, the change in imports equals the changes in demand and exports minus the change in supply.

Finally, a market equilibrium requires that, globally, the sum of the change in exports equals the total change in imports for each commodity:

$$
\text { 5) } \sum_{n=1}^{N}\left(\Delta X_{n}-\Delta M_{n}\right)=0 ;
$$

\footnotetext{
${ }^{21}$ An alternative Armington specification is available to ATPSM users but the closure used here gives more satisfactory results for this application where two-way trade is limited.
} 
Table A1. Coffee price elasticities in ATPSM for selected countries

\begin{tabular}{ccc}
\hline Brazil & Supply & Demand \\
Colombia & 0.70 & -0.15 \\
Indonesia & 0.23 & -0.15 \\
Vietnam & 0.12 & -0.40 \\
\hline
\end{tabular}

Source: Derived from FAO coffee model.

By transforming $\hat{D}, \hat{S}, \Delta X$ and $\Delta M$ and $\hat{P}_{w}$ to vectors with dimensions of 5832 $(162 * 36)$ by 1 , the equation system above can be simplified and solved by matrix inversion. Further details are available in UNCTAD (2002) ${ }^{22}$.

Over the time frame of the model, reflected in the elasticities, domestic prices fully reflect changes in world prices. There is full transmission. In other words, adjustment to price shocks has been completed, a process that takes perhaps five years on the supply side.

${ }^{22}$ The ATPSM model plus the documentation and data is downloadable from www.unctad.org/tab for free. 